\title{
PELUANG DAN TANTANGAN JURUSAN KOMUNIKASI DAN PENYIARAN ISLAM DALAM MENGHADAPI ERA DISRUPTIF 4.0
}

\author{
Zulkarnain, MA. \\ Institut Agama Islam Negeri Langsa
}

\begin{abstract}
Abstrak
Jurusan Kominikasi dan Penyiaran Islam FUAD IAIN Langsa di masa mendatang tidak akan mampu berkompetisi dalam tataran yang lebih mengglobal tanpa diimbangi dengan strategi komunikasi yang efektif dan transformatif. Memasuki abad ke-21 bangsa Indonesia dihadapkan pada berbagai tantangan besar berskala global. Sebagian besar tantangan itu muncul dari proses globalisasi yang terjadi sejak paruhan kedua abad ke-20 dan diperkirakan semakin intensif pada abad mendatang. Globalisasi tidak hanya mendorong terjadinya transformasi peradaban dunia melalui proses modernisasi, industrialisasi, dan revolusi informasi. Lebih dari itu juga akan menimbulkan perubahan-perubahan dalam struktur kehidupan bangsa-bangsa dunia, termasuk Indonesia. Memasuki abad baru bangsa Indonesia diperkirakan akan mengalami perubahanperubahan serba cepat dalam berbagai bidang kehidupan, baik dakwah, sosial, budaya, ekonomi, politik, pendidikan maupun di bidang teknologi
\end{abstract}

\section{Kata Kunci: Peluang dan Tantangan, Dakwah Era Disruptif 4.0}

\section{A. Pendahuluan}

Berbicara tentang pengembangan Jurusan/Prodi Komunikasi dan Penyiaran Islam tidak terlepas dari segudang persoalan yang melingkupinya. Di antaraya persoalan yang paling mendasar pada Jurusan Komunikasi Dan Penyiaran Islam saat ini adalah kurangnya sumber daya manusia dan lemahnya strategi ke depan dalam pengembangan etos dan profesionalisme keilmuannya. Berbagai macam cara dan strategi telah dilakukan oleh pengelolanya tapi masyarakat belum bersimpati banyak kepada Jurusan KPI. Hal ini menjadi pekerjaan rumah yang besar bagi para pengurus dan pemimpin lembaga ini dalam rangka menghadapi Era disrupsi 4.0.

Ketika berbicara tentang pengembangan institusi dan keilmuan dalam Islam, kedepan tantangannya makin beragam. Paling tidak, dapat dideskripsikan secara global ke dalam tiga dimensi. Dimensi pertama, tantangan global-postmodernisme yang antara lain bercirikan (1) timbulnya pemberontakan secara kritis terhadap modernitas; memudarnya kepercayaan pada agama yang bersifat transendental (meta narasi); dan semakin diterimanya pandangan pluralismerelativisme kebenaran; (2) meledaknya industri media massa, sehingga ia bagaikan perpanjangan dari sistem indera, organ dan saraf kita yang pada gilirannya membuat dunia menjadi terasa kecil. Lebih dari itu, kekuatan media massa telah menjelma bagaikan "agama" dan "tuhan" sekuler, dalam arti bahwa perilaku orang tidak lagi ditentukan oleh agama-agama tradisional, tetapi tanpa disadari telah diatur oleh media massa; (3) munculnya radikalisme etnis dan keagamaan. Fenomena ini muncul diduga sebagai reaksi atau alternatif ketika orang semakin ragu terhadap kebenaran sains, teknologi dan filsafat yang dinilai gagal memenuhi janjinya untuk membebaskan manusia 
dan kemanusiaan. (H.A.R. Tilaar,1998:205) Dalam terma H.A.R. Tilaar, masyarakat masa depan masyarakat abad 21, akan berciri pokok di antaranya adalah masyarakat "mega-kompetisi", yang menuntut kualitas secara fisik-intelektual dan moral.

Dimensi kedua, adalah ketertinggalan dunia Islam. Bahwa sejak enam abad terakhir praktis kepemimpinan dunia dipegang oleh Barat, setelah sebelumnya dunia Islam. Dunia Islam jauh ketinggalan dalam mengembangkan peradaban sains dan teknologi dan kreasi-kreasi lain. Islam sebagai paradigma syari'at dan teologi memang kelihatan masih kokoh (untuk tidak menyatakan jumud atau beku), tetapi Islam sebagai paradigma peradaban berada di luar panggung permainan, dan cenderung sebagai penonton yang "cemburu".(Komaruddin Hidayat,1998:152) Itu secara makro, dan dalam konteks mikronya, nampaknya tidak jauh beda. Bahwa mayoritas bangsa Indonesia adalah penganut Islam, maka secara "otomatis" yang "tertinggal" juga mayoritas penganut Islam tersebut. Sisi ini memberi warna tantangan tersendiri bagi "kalangan" Pendidikan Tinggi Islam khususnya UIN/IAIN/STAIN, yang idealnya perlu "turun tangan" lebih dulu.

Dimensi ketiga, ini yang paling langsung dan paling mendesak, adalah kondisi internal UIN/IAIN/STAIN (khusus Jurusan KPI) yang sekarang ini -menurut pengamatan H.A.R. Tilaar didirikan sesuai dengan tuntutan zaman atau kondisi ketika lembaga tersebut didirikan, yang tentunya dengan paradigma yang tidak lagi relevan dengan era global dewasa ini. Ketidakrelevanan tersebut terlihat dari dua sisi, (1) paradigmanya sangat sektoral, dan (2) visi serta misi yang dimilikinya sangat terbatas, dan karenanya hanya mungkin memenuhi satu sektor tertentu saja dari kebutuhan umat Islam Indonesia modern, tetapi tidak mungkin diharapkan untuk menghasilkan manusia-manusia yang kompetitif yang dapat unggul dalam persaingan masyarakat global (knowledge society) pada abad 21 yang akan datang. (H.A.R. Tilaar,1998:208-209)

\section{B. Kontekstualisasi Jurusan Komunikasi dan Penyiaran Islam di Era 4.0}

Dalam pengembangannya, Jurusan /Prodi KPI memiliki beberapa konsepsi dasar yang perlu selalu diingat dan dikontekstualisasikan semangat dan paradigma yang ada di dalamnya. Konsepsi dasar itu antara lain adalah:

1. Visi, adalah cara pandang jauh ke depan ke mana Jurusan Komunikasi Dan Penyiaran Islam harus dibawa agar dapat eksis, antisipatif dan inovatif. Visi tidak terikat waktu, menggambarkan layanan global yang berkelanjutan dan berlaku sebagai kerangka dasar bagi sistem perencanaan Jurusan KPI.

2. Misi, adalah suatu yang harus dilaksanakan oleh Jurusan/Prodi KPI agar tujuan organisasi dapat terlaksana dan berhasil dengan baik, disamping itu misi juga mengekspresikan alasan khas keberadaan Jurusan/prodi KPI, umumnya mengandung identifikasi tentang apa maksud, mengapa dan untuk siapa Jurusan KPI ini diadakan. 
3. Tujuan, adalah merupakan penjabaran/implementasi dari pernyataan misi. Tujuan pada hakekatnya merupakan sesuatu yang ingin dicapai dalam kurun waktu 1 sampai dengan 5 tahun.

4. Sasaran, adalah penjabaran dari tujuan, yaitu sesuatu yang akan dicapai/dihasilkan dalam jangka waktu tahunan, semesteran, triwu-lanan atau bulanan. Sasaran diusahakan dalam bentuk kuantitatif sehingga dapat diukur.

5. Prinsip, adalah falsafah dan tata nilai (core values) yang menggam-barkan bagaimana Jurusan Komunikasi Dan Penyiaran Islamdapat mengendalikan dan memotivasi diri dalam mengemban misi.

6. Perencanaan Strategis, adalah merupakan suatu proses yang berorientasi pada hasil yang ingin dicapai selama kurun waktu 1 sampai dengan 10 tahun dengan memperhitungkan potensi, peluang, dan kendala yang ada atau mungkin timbul. Rencana strategik mengandung visi, misi, tujuan, sasaran dan program yang realistis dan mengantisipasi masa depan yang diinginkan dan dapat dicapai.

7. Rencana Tindak (Action Plan), adalah jabaran strategi berupa rencana kegiatan yang akan dilakukan untuk mencapai setiap objective yang telah ditetapkan.

8. Analisis SWOT (Internal \& External Assessment), adalah analisis dan evaluasi baik secara internal terhadap kekuatan-kekuatan (strenghts) dan kelemahan-kelemahan (weaknesses) dari Jurusan Komunikasi Dan Penyiaran Islamsaat ini maupun secara eksternal terhadap peluang (opportunity) dan tantangan (threats) dari luar.

9. Isu Strategis, adalah kesulitan atau masalah yang perlu diantisipasi karena berpengaruh besar dan bermakna terhadap fungsi dan kinerja lembaga. Isu strategis terkait langsung dengan: (1) keluaran atau hasil yang merupakan dampak dari kinerja organisasi secara menyeluruh; (2) kontroversi pada anggota civitas akademika terhadap dampak tersebut; dan (3) konsekuensi dari suatu isu yang berupa perbedaan pendapat terhadap alokasi sumberdaya dan bervariasinya keluaran yang direncanakan.

10.Strategi Unggulan, adalah strategi yang diprioritaskan pencapaiannya dalam 5-10 tahun mendatang dengan didasarkan pada ketersediaan sumber daya pendukung.

Idealnya Jurusan Komunikasi Dan Penyiaran Islam harus mampu meneguhkan kembali fungsi pokoknya sebagai lembaga pendidikan tinggi bagi warganya. Sebagai lembaga pendidikan dan kader, fungsi terpentingnya menciptakan sumberdaya manusia muslim yang berkualitas. Yang dimaksud berkualitas adalah manusia yang mempunyai sikap produktif, berdaya saing tinggi dan mandiri. Hal ini sesuai dengan tuntutan dunia modern di abad global. Namun demikian, perlu ditekankan bahwa sumberdaya manusia yang hendak diciptakan itu, harus disertai dengan karakter cendekia dan islami. Sehingga, sikap produktif, berdaya saing tinggi dan kemandirian yang terbentuk adalah sikap yang dilandasi oleh semangat 'kecendekiawan' dan 'Islami'. 
Cendekiawan, merupakan karakter mencerminkan kepedulian yang tinggi terhadap lingkungan sosialnya. Manusia cendekia, memiliki responsibilitas yang tinggi terhadap persoalan yang terjadi di sekitarnya. Perwujudan sikap cendekia diharapkan muncul dalam aksi-aksi konkret membela kepentingan masyarakat banyak yang cenderung dilemahkan dalam banyak urusan. Sementara Islami menunjuk pada semnagat spiritual yang membungkus setiap gerak dan aksi tersebut. Jika prasyarat dunia modern yang meniscayakan adanya produktivitas, daya saing (kompetensi), dan kemandirian (independensi) itu berpadu dengan semangat cendekia dan religiusitas (islami), sungguh akan menjadi sebuah tipe manusia ideal masa depan; manusia yang seimbang antara basis prasyarat modernitasnya dengan semangat mentalitas religius sebagai landasan moralnya. Dengan demikian, generasi muda akan muncul sebagai generasi pengganti yang tidak ragukan lagi kapabilitasnya. Tidak sebagaimana yang terjadi sekarang ini, dimana bangsa kita telah mengalami kemandegan regenerasi karena tidak berjalannya katub-katub pembinaan generasi muda secara baik. Lantas, dimana andil dan peran Jurusan Komunikasi Dan Penyiaran Islam dalam menciptakan profil sumber daya manusia yang demikian tersebut?

Peran-peran yang dapat dilakukan dalam menciptakan sumberdaya manusia yang berkualitas, produktif, kompetitif, mandiri, cendekia dan islami antara lain:

a. Melakukan fungsi-fungsi pembinaan dan kaderisasi umat yang berorientasi pada kebutuhan riil masyarakat, dengan melakukan modifikasi pola-pola pembinaan dan kaderisasi yang sesuai dengan perkembangan zaman.

b. Membuka kesempatan yang luas bagi terjadinya dialekteka kemasyarakatan, dan selanjutnya melakukan keberpihakan (komitmen)secara jelas terhadap kepentingan masyarakat sesuai dengan visi dan misi perguruan tinggi.

c. Melakukan fungsi-fungsi pembinaan dan kaderisasi umat yang berorientasi pada kebutuhan riil masyarakat, dengan melakukan modifikasi pola-pola pembinaan dan kaderisasi yang sesuai dengan perkembangan zaman.

d. Membuka kesempatan yang luas bagi terjadinya dialekteka kemasyarakatan, dan selanjutnya melakukan keberpihakan (komitmen)secara jelas terhadap kepentingan masyarakat sesuai dengan visi dan misi perguruan tinggi.(Muhammad Thalhah Hasan,2003:221)

\section{Revitalisasi Peran Jurusan KPI Dalam Menyikapi Era Disruptif. 4.0}

Secara komprehensif, pengembangan institusi dapat dimaknai sebagai salah satu wujud reformasi pendidikan yang menawarkan kepada kampus untuk menyediakan pendidikan yang lebih baik dan memadai bagi para peserta didik. Otonomi dalam manajemen merupakan potensi bagi kampus untuk meningkatkan kinerja civitas akademika, menawarkan partisipasi langsung 
kelompok-kelompok terkait, dan meningkatkan pemahaman masyarakat terhadap pendidikan. Sejalan dengan jiwa dan semangat Jurusan Komunikasi Dan Penyiaran Islamsebagai agen sosial dalam bidang pendidikan, kewenangan kampus juga berperan dalam menampung konsensus umum yang meyakini bahwa sedapat mungkin keputusan seharusnya dibuat oleh mereka yang memiliki akses paling baik terhadap informasi setempat, yang bertanggung jawab terhadap pelaksanaan kebijakan dan yang terkena akibat-akibat dari kebijakan tersebut.

\section{Prospek Jurusan KPI dalam Menghadapi Era 4.0 : Tantangan dan Peluang}

Jurusan Komunikasi Dan Penyiaran Islam dengan segala program yang dimilikinya saat ini sangat membutuhkan strategi baru yang lebih berorientasi kepada masyarakat, sebab masyarakat merupakan pilot project yang harus terus dikembangkan sekaligus masyarakat menjadi basis dalam memperoleh in put yang berkualitas.

Untuk menuju kearah yang memberdayakan di kalangan masyarakat, Jurusan Komunikasi Dan Penyiaran Islam perlu menerapkan strategi ala Stephen R Covey dalam bukunya "'The Eight Habit" berbicara tentang pola manejemen hidup melalui delapan kebiasaan yang telah dipraktekkan oleh para manajer dan pengusaha sukses di seluruh dunia. beberapa strategi ala Steven tersebut adalah :

\section{Proaktif (be proactive)}

Sebagai pengayom, pemimpin dan institusi Jurusan Komunikasi Dan Penyiaran Islam kebiasaan proaktif sangat diperlukan agar semua kegiatan dan program yang telah direncanakan dapat terlaksana sebagai mana mestinya. Orang yang proaktif tidak pernah mengeluh, tidak pernah menyalahkan siapa pun dan apa pun atas keadaan yang dialaminya. Dimana proaktif selalu mencermati kegiatan apa yang dibutuhkan oleh komunitas pesantren dan masyarakat sekitarnya.(Stephen R. Covey, 2004:3-4)(Muhammad Zen, 2006:124)

\section{Mulai Dengan Akhir Dalam Pikiran (Begin With The End In Mind)}

Kebiasaan kedua ini menegaskan institusi Jurusan Komunikasi Dan Penyiaran Islam untuk melakukan aktivitas dan kegiatan mulai dengan akhir dalam pikiran. Maksudnya adalah institusi Jurusan Komunikasi Dan Penyiaran Islam harus memiliki tujuan yang jelas dalam mengembangkan institusi ke depan. Mempunyai tujuan berarti memiliki visi, misi, dan sasaran kebiasaan ini menunjukkan perlunya arah dan cara menjalani dan menentukan hal-hal yang utama dalam mengelola Jurusan KPI. Hal-hal utama mengelola institusi adalah terwujudnya tujuan-tujuan berharga secara progresif dan seimbang dalam aspek kehidupan, baik secara pisik, emosional, intelektual, sosial, finansial, mental maupun spiritual.

Kebiasaan kedua ini mengajarkan agar kita memilih dan menuliskan program kehidupan kita di masa mendatang, menentukan apa yang kita tuju dalam kehidupan ini, apakah itu sebagai akademisi, atau sebagai manusia secara individu. 


\section{Dahulukan Yang Utama (Put First Things First)}

Mendahulukan yang utama merupakan kebiasaan yang menuntut integritas, disiplin, dan komitmen. Kebiasaan ketiga ini sebagai perwujudan dari skala prioritas pemimpin Jurusan Komunikasi Dan Penyiaran Islamdalam memilih kegiatan sesuai dengan kemampuan yang dimiliki, baik dari aspek keuangan, maupun sumber daya lainnya, disamping juga membutuhkan Needs Assesment (rumusan kebutuhan) para komunitas akademisi dan mayarakat secara umum. Memilih dan memilah hanya melakukan hal-hal yang utama yaitu aktivitas-aktivitas yang akan membawa pada tercapainya tujuan yang telah ditetapkan oleh semua aspek komponen. Kebiasaan ketiga ini menekankan pentingnya memanfaatkan waktu dengan sebaik-baiknya. (Stephen R. Covey, 2004:3-4)

\section{Berpikir Untuk Berhasil Menang (Think Win-Win)}

Kebiasaan keempat ini mengharapkan dalam memenejerial Jurusan Komunikasi Dan Penyiaran Islamtidak ada unsur yang dirugikan baik karyawan, dosen, dan masyarakat. Kebiasaan ini berasal dari latihan setiap individu untuk sebuah kejujuran (honesty; menyesuaikan kata dengan perbuatan), integritas (integrity; menyesuaikan perbuatan dengan perkataan), kematangan (maturity), dan mentalitas kelimpahan (aboundance mentality), keyakinan bahwa karunia Allah swt tersedia tampa batas bagi siapa pun yang mengikuti causality law atau ketentuan hukumnya. Sebagai lawanan dari mentalitas kelangkaan, (search mentality).

Kehadiran kebiasaan ini diharapkan mampu memotivasi pimpinan, dosen, karyawan Jurusan Komunikasi Dan Penyiaran Islamdalam menyusun sebuah perencanaan, pengorganisasian, pergerakan atau pengendalian manajemen Jurusan Komunikasi Dan Penyiaran Islamyang mengarah kepada asas manfaat sesuai dengan "N W D" (need/kebutuhan, want/ keinginan, dan demand/permintaan) semua lapisan komponen masyarakat.

\section{Berusaha Memahami Lebih Dahulu Baru Minta Dipahami (Seek First To Understand Than To Be Understood)}

Kebiasaan kelima ini menunjukkan kunci kesuksesan mengelola dan mengembangkan Jurusan Komunikasi Dan Penyiaran Islam adalah saling memahami, membantu, mengerti, dan saling, tidak hanya bertepuk sebelah tangan, harus dua tangan agar serasi, senada, dan seirama, jika pengasuh, pembina, pengayom ingin dikasihi dan dipahami sekaligus dimengerti oleh masyarakat dalam membangun dan mengembangkan Jurusan KPI. Kebiasaan inilah yang merupakan simbolisasi setiap insan untuk menghormati, memahami hak orang lain kalau ingin dihormati dan ingin berhasil dalam mencapai tujuan.

\section{Wujudkan Sinergi ( Sinergize)}

Bersinergi berarti keseimbangan dapat dicapai. Sinergi dapat dicermati jika ada kerjasama yang harmoni antara pimpinan, dosen, staf kepegawaian dan masyarakat (human capital). Jurusan Komunikasi Dan Penyiaran Islam harus memiliki akses teknologi 
informasi (information capital) yang memadai agar pimpinan institusi memenej Jurusan sesuai dengan perkembangan teknologi zaman, terpola kerja sama antar sesama dalam mensukseskan kegiatan dan adanya proses pembelajaran dan pengembangan organisasi (organizational capital) sehingga terbentuk budaya organisasi Jurusan Komunikasi Dan Penyiaran Islamsesuai dengan tuntutan zaman dan tuntunan ilahi.

\section{Mengasah Gergaji ( Sharpen The Way)}

Kebiasaan ketujuh ini menekankan pentingnya secara terus menerus pempinan Jurusan Komunikasi Dan Penyiaran Islammengasah gergaji fisik, emosional, intelektual, sosial, finansial, mental dan spiritual. Artinya, institusi Jurusan Komunikasi Dan Penyiaran Islamsepatutnya memperbaiki terus menerus kinerja keinstitusian, manajemen, kegiatan, dan bangunan fisik institusi melalui learning by prosess (belajar dengan proses). Dari waktu ke waktu hendaknya pimpinan terus berjuang meningkatkan kesuksesan tersebut dalam kegiatan pengembangan. Islam menganjurkan kepada kita untuk setiap saat memperbaiki prestasi yang digapai, orang Islam adalah orang yang hari ini harus lebih baik dari hari kemarin, dan hari esok harus lebih baik dari hari ini. Kebiasaan ini mengantarkan setiap insan akademisi untuk sibuk memperbaiki dirinya sendiri dan organisasinya dalam mengelola semua sumber daya institusi, sehingga tidak mempunyai waktu tersisa untuk mencari-cari kesalahan dan aib orang lain.

\section{Temukan Suara Anda Dan Ilhami Orang Lain Menemukan Suara Mereka (Find Your Voice And Inspire Others To Find Their )}

Kebiasaan ini mengajarkan bahwa pengelola harus menemukan suara hati mereka, mengapa mereka terpilih jadi pengelola pesantren apa manfaatnya bagi dia sendiri, masyarakat, negara dan bangsa? Sehingga pertanyaan tersebut menginspirasikan bagi setiap individu termasuk pimpinan institusi untuk menjadi bermanfaat bagi lainnya saat menjadi institusi maupun tidak. Orientasi pengelola akan terpatri dalam jiwa raganya membuat skim aneka varian kegiatan fakultas yang dapat memberikan kontribusi riil dan bermanfaat bagi institusinya, masyarakat, agama, bangsa dan negara.

Kemampuan pimpinan menemukan suara (intuisi) mereka tentunya dianugrahkan Allah swt sejak lahir, ketika pimpinan Jurusan Komunikasi Dan Penyiaran Islamsukses mengembangkan lembaganya, sepatutnya masyarakat, pemerintah dan negara memberikan apresiasi yang setinggitingginya karena di perguruan tinggilah tempat dan markas pengkaderan penerus bangsa yang beretika dan berakhlak mulia.

Hadirnya pola menejemen yang dikembangkan oleh Sthepen R. Covey melalui The Eight Habit memberikan warna tersendiri bagi perbaikan kinerja sebuah organisasi, perusahaan termasuk di dalamnya pengelolaan Jurusan Komunikasi Dan Penyiaran Islam yang notabene memiliki problematika dan multi kendala. Solusi atas tersebut tentunya dengan memberikan arahan baru bagi para insan akademis Jurusan Komunikasi Dan Penyiaran Islam dengan sedikit meminjam teori 
Stephen ini meskipun secara substansial dalam ajaran Islam sudah termaktub hal-hal seperti yang diteorikan oleh Covey tersebut. Tidaklah salah jika hal-hal yang kontemporer kita coba berusaha mengimplementasikan dalam pengembangan seluruh aktivitas yang berkaitan dengan organisasi, sekecil apapun apalagi lembaga yang bernama Jurusan Komunikasi Dan Penyiaran Islam yang mengelola banyak orang dan mendidik putra bangsa yang akan menjadi penerus negara ini.

Untuk rekonstruksi kemajuan Jurusan Komunikasi Dan Penyiaran Islam perlu dilakukan analisis terhadap kelemahan, peluang dan tantangan Jurusan Komunikasi Dan Penyiaran Islamatau bagaimana prospek Jurusan ini dari kondisi sekarang dan pertandanya ke depan. Beberapa komponen penting yang harus diperhatikan adalah sebagai berikut:

\section{a) Analisis Kelemahan Dan Ancaman Yang Mendesak Untuk Diatasi.}

\section{1) Kelemahan :}

Sebagian kecil program-program yang dicanangkan oleh Jurusan Komunikasi Dan Penyiaran Islamuntuk mencapai visi, misi masih belum maksimal dalam pelaksanaan.

Program kerja yang sangat padat antara fungsi sebagai dosen dan sebagai pejabat struktural menyebabkan beban pekerjaan dosen semakin berat yang berakibat menurunnya performance dosen.

Penjamin mutu belum maksimal di tingkat Jurusan Komunikasi Dan Penyiaran Islam karena fungsi kontrol dari Institut masih belum berjalan dengan baik.

Informasi masuk Jurusan Komunikasi Dan Penyiaran Islambelum optimal.

Prestasi mahasiswa di tingkat regional dan nasional masih minim.

Partisipasi mahasiswa dalam kegiatan akademik dan non akademik di tingkat nasional masih minim.

Masih sedikit Dosen yang mengikuti forum ilmiah tingkat nasional maupun Internasional.

Karya ilmiah dosen belum ada yang diterbitkan di jurnal internasional

Belum optimalnya pelayanan sarana dan prasarana untuk sistem informasi

\section{2) Ancaman:}

Adanya Perguruan Tinggi lain di wilayah sekitar Aceh yang memiliki Program Studi yang sama dan telah berdiri lebih dulu yang lebih baik.

Pengembangan sarana dan prasarana yang ada perlu dana yang besar.

Perguruan tinggi lain yang lebih aktif dalam memanfaatkan tawaran dana penelitian, pengabdian kepada masyarakat dari pemerintah dan swasta.

Tuntutan masyarakat yang semakin tinggi terhadap sarpras akademik dan lulusan yang berprofesi PNS. 


\section{b) Analisis kekuatan dan peluang untuk mengatasi kelemahan dan ancaman}

\section{1) Kekuatan :}

Tersedianya SDM berkualitas dan profesional yang memadai untuk mewujudkan visi, misi, tujuan dan sasaran Jurusan Dakwah.

Adanya struktur organisasi dan pembagian tugas yang jelas pada tiap komponen sehingga tidak ada tumpang tindih pekerjaan sehingga fungsi masing-masing komponen bisa berjalan baik untuk menjaga performance Dosen.

Umpan balik yang aktif dari Dosen dan mahasiswa mampu meningkatkan kualitas pembelajaran.

Penjamin mutu di tingkat Jurusan Komunikasi Dan Penyiaran Islammampu menjalankan fungsi dengan baik sehingga mampu menjaga kualitas Dosen, kualitas perkuliahan dan kualitas mahasiswa dan lulusan.

Animo calon mahasiswa masuk yang cenderung meningkat dari tahun ke tahun yang menjamin keberlangsungan Jurusan KPI.

Keterlibatan mahasiswa dalam berbagai komisi/ kegiatan akademik dan non akademik yang memungkinkan mahasiswa semakin berkembang.

Pelayanan akademik dan non akademik bagi mahasiswa cukup memadai.

Jumlah Dosen tetap yang memiliki kualifikasi sesuai dengan Jurusan Komunikasi Dan Penyiaran Islam dan telah berpendidikan S2.

Semua Dosen yang memiliki kualifikasi sesuai dengan Jurusan Komunikasi Dan Penyiaran Islamsudah membuat karya akademik dan ikut dalam kegiatan ilmiah.

Jurusan Komunikasi Dan Penyiaran Islam telah mengusahakan bantuan pendidikan untuk studi lanjut sehingga beberapa Dosen sedang studi lanjut S2.

\section{2) Peluang :}

Kepedulian yang tinggi dari Pemko Langsa, Organisasi Massa/Yayasan di Kota Langsa dan masyarakat umum terhadap Jurusan Komunikasi Dan Penyiaran Islam yang terbukti dengan bantuan dana yang diberikan untuk beasiswa, penelitian dan pengabdian masyarakat.

Kesadaran masyarakat yang mulai tinggi terhadap pentingnya pendidikan terutama pendidikan yang terintegrasi antara ilmu agama dan teknologi memberi peluang semakin banyak masyarakat pengguna yang mendaftar kuliah.

Respon positif dari masyarakat terhadap performance Dosen Jurusan Komunikasi Dan Penyiaran Islam di masyarakat yang memungkinkan mudahnya upaya pengembangan program-program Jurusan Komunikasi Dan Penyiaran Islamyang berhubungan dengan masyarakat umum. 
Adanya sistem kontrol masyarakat terhadap mutu dan kualitas pendidikan yang bisa dijadikan masukan dan rujukan untuk perbaikan Jurusan KPI.

Semakin banyaknya pembukaan SMU-SMU/MAN baru yang memungkinkan semakin banyaknya siswa yang melanjutkan kuliah.

Semakin majunya tekhnologi informasi yang memungkinkan sosialisai penerimaan mahasiswa baru bisa menjangkau seluruh wilayah di Indonesia.

Perkembangan sistem informasi dan teknologi sebagai penunjang kompetensi Dosen semakin mudah diakses sehingga Dosen bisa semakin meningkatkan kompetensi dan kualifikasinya.

Kesempatan pendanaan studi lanjut dalam dan luar negeri melalui beasiswa yang makin tinggi.

Semakin berkembangnya kemajuan IPTEK membuka peluang untuk meningkatkan proses pembelajaran.

\section{E. Strategi Dasar Pengembangan Jurusan Komunikasi Dan Penyiaran Islam}

Dalam rangka mewujudkan visi dan misi Fakultas ditempuh melalui pengembangan sumber daya manusia, pengembangan program studi, pengembangan sarana fisik, pengembangan teknologi, pengembangan organisasi dan manajemen Fakultas, penggalian sumber dana yang sustainable, menciptakan lingkungan yang kondusif, dan meningkatkan citra Fakultas.

1. Pengembangan Kualitas Sumber Daya Manusia Pengembangan Sumber Daya Manusia (SDM) bagi tenaga edukatif diarahkan agar menjadi tenaga yang profesional, mampu bersaing di tingkat nasional serta mampu berpartisipasi dalam forum-forum regional dan forum-forum internasional, memiliki integritas pribadi yang baik, dan mempunyai komitment yang kuat terhadap Lembaga Pendidikan. Sedangkan bagi tenaga admisnistratif, pengembangan diarahkan untuk menjadi tenaga profesional yang lebih berorientasi pada peningkatan pelayanan ketimbang sebagai. Birokrat

2. Pengembangan Jurusan Komunikasi Dan Penyiaran Islam

Jurusan Komunikasi Dan Penyiaran Islam harus disesuaikan dengan perkembangan ilmu pengetahuan dan teknologi, kebutuhan pasar tenaga kerja, dan kebutuhan pembangunan bangsa dan kemanusiaan pada umumnya. Untuk itu, kurikulum pada setiap Program Studi harus berorientasi pada pengembangan kemampuan penalaran, keterampilan mengaplikasikan Iptek, dan menjunjung tinggi nilai-nilai moral dan etika. 


\section{Pengembangan Sarana Fisik}

Pengembangan sarana fisik diupayakan untuk dapat memenuhi kebutuhan proses belajar mengajar dan untuk menunjang kegitan dosen dalam melakukan berbagai kegiatan serta pelayanan kepada mahasiswa dan dosen.

4. Pengembangan Teknologi

Kemajuan teknologi dibidang sistem informasi dan audio-visual harus dimanfaatkan dalam meningkatkan kuantitas dan kualitas proses belajar mengajar, penelitian, publikasi ilmiah, dan pelayanan administrasi.

5. Pengembangan Organisasi dan Manajemen.

Untuk mewujudkan suatu organisasi dan manajemen yang efektif dan efisien, maka organisasi dan manajemen di Jurusan Komunikasi Dan Penyiaran Islam perlu dikembangkan atas dasar profesionalisme, transparansi, dan akuntabilitas. Selain itu perlu diciptakan reward system yang adil untuk meningkatkan motivasi dan kebersamaan seluruh warga Jurusan.

6. Pengembangan Lingkungan yang Kondusif

Untuk menciptakan lingkungan yang kondusif, maka perlu ditum-buhkan budaya akademik (academic culture) bagi mahasiswa dan dosen dan corporate culture bagi pejabat struktural dan tenaga administratif.

\section{Penggalangan Dana yang sustainable}

Dalam mengantisipasi otonomi Perguruan Tinggi, perlu lebih diintensifkan sumber-sumber dana yang konvensional dan non konvensional.

8. Peningkatan Citra Jurusan Komunikasi dan Penyiaran Islam

Peningkatan citra Jurusan Komunikasi Dan Penyiaran Islam diperlukan untuk menyebarluaskan keberadaan Jurusan KPI dengan berbagai program kegiatan yang ditawarkan dan output yang dihasilkan.

\section{E. Penutup}

Pendidikan tinggi sebagai lembaga pendidikan yang diharapkan menghasilkan manusiamanusia unggul dalam berbagai bidang keahlian. Perguruan tinggi sebagai sub sistem pendidikan secara otomatis akan mengimplementasikan isu strategis daya saing bangsa dalam program dan kegiatan yang lebih spesifik, terukur, jelas ketercapaiannya, realistik, dan memiliki rentang waktu dalam pelaksanaannya. Untuk merancang program dan kegiatan peningkatan daya saing perguruan tinggi perlu dituangkan dalam suatu prencanaan strategis dalam upaya mendapatkan in put yang berkualitas dan menghasilkan out put yang berhasil guna, paling tidak tercermin dari misi tentang peningkatan daya saing perguruan tinggi, perspektif tentang daya saing perguruan tinggi, tujuan yang hendak dicapai dalam peningkatan daya saing perguruan tinggi, dan assessment atau pengukuran hasil kinerja. 


\section{DAFTAR KEPUSTAKAAN}

H.A.R. Tilaar, Beberapa Agenda Reformasi Pendidikan Nasional: Dalam Perspektif Abad 21, (Magelang: Tera Indonesia, 1998).

H.A.R. Tilaar, Manajemen Pendidikan Nasional, (Bandung: Remaja Rosda Karya, 2001).

H.A.R. Tilaar, Paradigma Baru Pendidikan Nasional, (Jakarta: Rineka Cipta, 2000).

Haidar Daulay, IAIN Di Era Globalisasi: Peluang dan Tantangan dari Sudut Pendidkan Islam, (Yogyakarta: Tiara Wacana, 1998).

Komaruddin Hidayat, "Agama Dan Postmodernisme" dalam Tragedi Raja Mida: Moralitas Agama dan Krisis Modernisme, (Jakarta: Paramadina, 1998).

Muhammad Thalhah Hasan, Islam dan Sumber Daya Manusia, (Jakarta: Laborta Press, 2003).

Muhammad Zen, Manajemen Masjid Berbasis " The Eight Habits", Jurnal Kajian Dakwah Dan Komunikasi UIN Sarif Hidayatullah Jakarta, Vol.VIII, NO.1,Juni 2006.

Stepehen W. Litteljohn \& Karen A. Foss, Theories of Human Communication, (Belmots: Thomson Wadsworth, 2005.

Stephen R. Covey, The Eight Habit From Effectiveness to Greatness,New York : Free Press, 2004. 